\title{
Theoretical study on ionization of boric acid in aqueous solution by ab initio and DFT methods at $\mathrm{T}=298.15 \mathrm{~K}$
}

\author{
Hoodad Ghanizadeh $^{1}$, Farhoush Kiani ${ }^{1, *}$, Fardad Koohyar, ${ }^{2,3, *}$, Bahareh Khanlarzadeh ${ }^{1}$ \\ ${ }^{1}$ Department of Chemistry, Faculty of Science, Ayatollah Amoli Branch, Islamic Azad University, \\ Amol, Iran \\ ${ }^{2}$ Division of Computational Physics, Institute for Computational Science, Ton Duc Thang University, \\ Ho Chi Minh City, Vietnam \\ ${ }^{3}$ Faculty of Applied Sciences, Ton Duc Thang University, Ho Chi Minh City, Vietnam
}

Corresponding authors e-mail addresses: fardadkoohyar@tdtu.edu.vn

farhoush_kiani@yahoo.com

\begin{abstract}
Boric acid has antifungal and antiviral properties. It is used in various prescription pharmaceutical products. In this research work, we theoretically calculated the $\mathrm{pK}_{\mathrm{a}}$ value of boric acid in aqueous solution by ab initio and DFT methods at $\mathrm{T}=298.15 \mathrm{~K}$. To explain the determined acidic dissociation constant, the various molecular conformations and solutesolvent interactions of the species of boric acid were considered. The basis set at the $\mathrm{B} 3 \mathrm{LYP} / 6-31+\mathrm{G}$ (d) level of theory was selected for DFT calculations. We analyzed the formation of intermolecular hydrogen bonds between several species of boric acid and water molecules through Tomas's method. The result shows that there is a comparable agreement between the experimentally and theoretically determined $\mathrm{pK}_{\mathrm{a}}$ values for boric acid.
\end{abstract}

Keywords: Boric Acid, Acidic Dissociation Constant, DFT, Ab Initio.

\section{Introduction}

Boric acid is a weak acid that forms a white and water-soluble powder. ${ }^{1}$ It can be naturally found in seawater, many plants, and most fruits. Boric acid has been used as mild antiseptics or bacteriostats in eyewashes and mouthwashes. The aqueous solution of boric acid are topically used for ophthalmic irrigation to cleanse, refresh, and soothe irritated eyes and uses for removal of loose foreign material, air pollutants or chlorinated water. ${ }^{2}$

Boric acid is predominantly eliminated unchanged by the kidney; small amounts are also excreted into sweat, salvia, and faces. Boric acid is concentrated in the brain and liver. ${ }^{3}$ Boric acid and its derivatives have been shown to promote riboflavinuria in both animals and man. ${ }^{4}$ 
Metabolism of inorganic borates by biological systems is not feasible because the excessive energy is required to break the boron-oxygen bond. Inorganic borates, in low concentrations, convert to boric acid at physiological $\mathrm{pH}$ in the aqueous layer overlying mucosal surfaces prior to absorption. ${ }^{5}$

Studies of the acidity of organic compounds are important and play a very significant role in the evaluation of activity, reaction mechanisms, and structure of organic compounds.

Equilibrium constants for ionization reactions are usually called ionization constants or acidic dissociation constants $\left(\mathrm{pK}_{\mathrm{a}}\right)$. The $\mathrm{pK}_{\mathrm{a}}$ is an important physico-chemical parameter in drug absorption. Many drug compounds include at least one acid and/or basic group, and the ionization state of these groups play an important role in determining the physico-chemical properties of compound. Information about the $\mathrm{pK}_{\mathrm{a}}$ value of compounds plays a major role in the expansion of drug formulations. ${ }^{6-8}$

The reliable and accurate methods for calculating relative and absolute $\mathrm{pK}_{\mathrm{a}}$ values are important for understanding of the effective $\mathrm{pK}_{\mathrm{a}}$ values in molecules. Some studies detailing with the acid-base properties of compounds in aqueous solutions and in gas phase are also available. ${ }^{9}$ Different experimental procedures are frequently used for the determination of acidity constants. These methods are high-pressure liquid chromatography (HPLC), liquidliquid partitioning chromatography (LLPC), and methods that involve potentiometric titrations or spectrophotometric determination in water or in mixtures of solvents. Manov et al. determined the ionization constant of boric acid and the $\mathrm{pH}$ of certain borax-chloride buffer solutions from 0 to $60^{\circ} \mathrm{C} .{ }^{10}$ Arcis et al. determined the ionization of boric acid in water from $298 \mathrm{~K}$ to $623 \mathrm{~K}$ by AC conductivity and Raman spectroscopy. ${ }^{11}$ Dickson carried out E.m.f. measurements using the cell: Pt | H2(g,101.325 kPa) | borax in synthetic seawater | $\mathrm{AgCl}$; Ag over the temperature range $273.15-318.15 \mathrm{~K}$, and at five salinities from 5 to 45 . The obtained results of this research work had been used to calculate the stoichiometric (ionic medium) dissociation constant for boric acid in seawater media on the "total" hydrogen ion scale. $^{12}$

For boric acid, the values of $\mathrm{pK}_{\mathrm{a}}$ can be calculated using ab initio and DFT methods. ${ }^{13-18}$ These computational methods have an important advantage. In these methods, the important structural properties of molecule, in solution, such as dihedral angle between the indicated atoms (D); total atomic charge (Muliken) (q); bond lengths between the indicated atoms (d), and bond angles (A) are calculated. These structural properties can be used in research works as well as various industries. 
In DFT method, the calculation of electronic structure was performed with density functional theory and the electrostatic features were modeled through external charge distributions and continuum dielectrics. The Polarizable Continuum Model (PCM) using the integral equation formalism variant (IEFPCM) is the default SCRF method. This method creates the solute cavity via a set of overlapping spheres. It was initially devised by Tomasi and coworkers and Pascual-Ahuir and coworkers. Tomasi's method allowed us to prove that cations, neutral molecules, and anions form IHBs with some molecules of water. ${ }^{19}$

The paper deals with the influence of factors such as the self-Consistent Reaction Field (SCRF) model applied, choice of a particular thermodynamic equation, atomic radii used to build a cavity in the solvent (water), optimization of geometry in water, inclusion of electron correlation, and the dimension of the basis set on the solvation free energies and on the calculated $\mathrm{pK}_{\mathrm{a}}$ values. In this paper, the $\mathrm{pK}_{\mathrm{a}}$ value of boric acid was calculated in aqueous solution by ab initio and DFT method and temperature of $25^{\circ} \mathrm{C}$. We investigated the molecular conformations and solute-solvent interactions of the cation, anion, and neutral species of boric acid to explain the obtained acidic dissociation constants.

\section{Computational method}

Initially, the structure of species of boric acid was optimized by semi empirical PM3 method in program Hyper Chem (CS Chem 3D version 5.0). All calculations about geometries of the initial and solvated molecules in water were done using Gaussian 09 program package. DFT calculations were carried out using the hybrid exchange - correlation functional of Becke, Lee, Yang, and Parr (B3LYP) and the Gaussian 6-31G (d) basis set was used. ${ }^{20}$

To analyze the solvent effects on all species involved in the selected ionization reaction, the polarized continuum model (PCM) of Tomasi et al. was used. In this method, the solvent is represented as a structure less polarizable medium characterized by its dielectric constant. ${ }^{21}$ Finally, we selected the solvation of the species by means of intermolecular hydrogen bonds (IHBs) that involve one molecule of the mentioned species and some molecules of water.

\section{Results and Discussion}

The trend of a molecule to lose its $\mathrm{H}^{+}$is quantified as $\mathrm{pK}_{\mathrm{a}}$. Boric acid is a weak acid and it has three acid groups. A proton can separate from hydroxyl group to give ionized specie (Fig. 1). This concept of microscopic ionization constant is shown in the Eq. 1: 
$\mathrm{k}=\frac{\left[\mathrm{H}^{+}\right]\left[\mathrm{B}(\mathrm{OH})_{2} \mathrm{O}^{-}\right]}{\left[\mathrm{B}(\mathrm{OH})_{3}\right]}$

The total free energies (in Hartree and $\mathrm{kJ} \cdot \mathrm{mol}^{-1}$ ) for the single and solvated species of boric acid, in water, were calculated at the B3LYP/6-31+G (d) level of the theory, using Tomasi's method, at $\mathrm{T}=298.15 \mathrm{~K}$ and the results were showed in Table 1 . This table shows that the total free energy for various species of boric acid increases by increasing the number of water molecules. It shows that the solvation process causes to increase the total free energy for various species of boric acid. In other word, solvation of the boric acid is an endothermic process. The values of total free energy for various species of boric acid (Table 1) were applied to calculate $\mathrm{pK}_{\mathrm{a}}$ value of boric acid. In addition, these data help us to suggest proper reaction regarding deprotonation process of boric acid.

Various reactions including the neutral and anion species of boric acid were considered in an excel program and some of these reactions were not further considered because their equilibrium constants are not comparable with experimental ones. The selected equation for deprotonation process of boric acid as well as the experimentally determined and theoretically calculated $\mathrm{pK}_{\mathrm{a}}$ have been shown in Table 2 .

\section{Ionization constant of boric acid:}

In aqueous solutions, the molecule of boric acid can involve in below reaction:

$\mathrm{H}_{3} \mathrm{~L}\left(\mathrm{H}_{2} \mathrm{O}\right)_{4}+\mathrm{OH}^{-} \rightleftharpoons \mathrm{H}_{2} \mathrm{~L}^{-}\left(\mathrm{H}_{2} \mathrm{O}\right)_{3}+2 \mathrm{H}_{2} \mathrm{O} \quad K_{\mathrm{c}}$

In the above reaction, $\mathrm{H}_{3} \mathrm{~L}\left(\mathrm{H}_{2} \mathrm{O}\right)_{4}$ (Fig. 2A) is the neutral specie of boric acid solvated with four molecules of water and $\mathrm{H}_{2} \mathrm{~L}^{-}\left(\mathrm{H}_{2} \mathrm{O}\right)_{3}$ (Fig. 2B) represents the anion specie of boric acid solvated with three water molecules.

During reaction of Eq. 2, the autopyrolysis of two water molecules, in pure water, can occur as the below:

$2 \mathrm{H}_{2} \mathrm{O} \rightleftharpoons \mathrm{OH}^{-}+\mathrm{H}_{3} \mathrm{O}^{+} \quad K_{\mathrm{w}}=1.008 \times 10^{-14}$

The very low amount of $K_{\mathrm{w}}$ shows that a few water molecules are ionized in pure liquid water.

The reaction of Eq. 4 can be obtained by combining Eqs. 2 and 3:

$\mathrm{H}_{3} \mathrm{~L}\left(\mathrm{H}_{2} \mathrm{O}\right)_{4} \rightleftharpoons \mathrm{H}_{2} \mathrm{~L}^{-}\left(\mathrm{H}_{2} \mathrm{O}\right)_{3}+\mathrm{H}_{3} \mathrm{O}^{+} \quad K_{\mathrm{a}}$

It is clear that the value of $K_{\mathrm{a}}$ can be calculated using $K_{\mathrm{c}}$ and $K_{\mathrm{w}}$ as the below:

$K_{\mathrm{a}}=K_{\mathrm{c}} \times K_{\mathrm{w}}$ 
Eq. 5 was applied to calculate the values of the ionization constant of boric acid, $K_{\mathrm{a}}$, in water at $\mathrm{T}=298.15 \mathrm{~K}$. The theoretically calculated value of $\mathrm{pK}_{\mathrm{a}}$ for boric acid at $\mathrm{T}=298.15 \mathrm{~K}$ is shown in Table 2. As it can be seen in this table, there is a good agreement between experimentally determined and theoretically calculated $\mathrm{pK}_{\mathrm{a}}$ values of boric acid at this temperature.

Table 3 shows the optimized values of structural properties for the anion and neutral species of boric acid, in water, obtained at the B3LYP/6-31+G (d) level of theory with Tomasi's method at $\mathrm{T}=298.15 \mathrm{~K}$.

As it can be seen in Table 3, for boric acid, the values of qo4 for $\mathrm{HL}^{-}\left(\mathrm{H}_{2} \mathrm{O}\right)_{3}$ and $\mathrm{H}_{2} \mathrm{~L}\left(\mathrm{H}_{2} \mathrm{O}\right)_{4}$ are -1.104481 and -0.907847 , respectively. It shows that the absolute value of electrical charge around $\mathrm{O}_{4}$ atom in $\mathrm{HL}^{-}\left(\mathrm{H}_{2} \mathrm{O}\right)_{3}$, compared to that of in $\mathrm{H}_{2} \mathrm{~L}\left(\mathrm{H}_{2} \mathrm{O}\right)_{4}$, increases and it can imply to separate $\mathrm{H}^{+}$form $\mathrm{O}_{4}$ atom during deprotonation process of boric acid in water.

\section{Study on H-bonding between selected species of boric acid and water}

The structural properties of specie, solved in water, can help us to understand the interaction between this specie and water (H-bonding). One of the most important of these structural properties is the bond length between the indicated atoms form solute and solvent (water) molecules (in $\AA$ ). These data, for neutral and cation species of boric acid, are listed in Table 3. The power of hydrogen bonds can be classified as strong (bond length is between $1.2 \AA$ to $2.2 \AA$ and the angle is between $175^{\circ}$ to $180^{\circ}$ ), moderate (bond length is between $1.5 \AA$ to 2.2 $\AA$ and the angle is between $130^{\circ}$ to $180^{\circ}$ ), and weak (bond length is between $2.2 \AA$ to $3.2 \AA$ and the angle is between $90^{\circ}$ to $\left.150^{\circ}\right) .^{22}$ As it can be seen in Table 3 , for $\mathrm{H}_{2} \mathrm{~L}\left(\mathrm{H}_{2} \mathrm{O}\right)_{4}$, the bond length between atom $\mathrm{H}_{6}$, from boric acid, and $\mathrm{O}_{9}$, from water, is $2.124582\left(\mathrm{dH}_{6} \mathrm{O}_{9}=\right.$ 2.124582). In addition, for $\mathrm{H}_{2} \mathrm{~L}^{-}\left(\mathrm{H}_{2} \mathrm{O}\right)_{3}$, the bond length between atom $\mathrm{O}_{2}$, from boric acid, and $\mathrm{H}_{19}$, from water, is $2.098563\left(\mathrm{dH}_{19} \mathrm{O}_{2}=2.098563\right)$. These data shows that for boric acid, the power of $\mathrm{H}$-bonding between $\mathrm{H}_{2} \mathrm{~L}\left(\mathrm{H}_{2} \mathrm{O}\right)_{4}$ and water and also, between $\mathrm{H}_{2} \mathrm{~L}^{-}\left(\mathrm{H}_{2} \mathrm{O}\right)_{3}$ and water are classified as moderate. It must be noted that $\mathrm{IHB}_{\mathrm{s}}$ data can be used in the design of benefit and help us to predict Nano drug. ${ }^{7}$

\section{Conclusion}

In this research work, we showed the feasibility of a theoretical method, DFT and ab ignition, to calculate the ionization constants of boric acid at $\mathrm{T}=298.15 \mathrm{~K}$. As a result, we selected various acid-base reaction that include the solvation of the hydrogen, hydroxyl ions, and 
other anions or neutral molecules in protic solvents such as water, which process a high hydrogen-bond-donor capability. The calculations performed at the B3LYP/6-31+G(d) levels of theory using Tomasi s method allowed us to prove that neutral molecules and anions form $\mathrm{IHB}_{\mathrm{s}}$ with some molecules of water. In addition, the comparison between experimentally determined and theoretically calculated $\mathrm{pK}_{\mathrm{a}}, \mathrm{s}$, for boric acid, shows that there is a good agreement between them at $298.15 \mathrm{~K}$.

\section{References:}

1. Boeseken $\mathrm{J}$, The use of boric acid for the determination of the configuration of carbohydrates. Adv Carbohydr Chem. 1949; 4: 189-210.

2. Ishii Y, Fujizuka N, A Fatal case of acute boric acid poisoning. J Toxicol: Clinical Toxicology. 1993; 31: 345-352.

3. Goldbloom RB, Goldbloom A, Boric acid poisoning. J Pediatr. 1953; 43: 631-643.

4. Krieger R. Handbook of pesticide toxicology, Academic press, San Diego, California, 2001. Vol 2, page 1434.

5. Vaziri ND, Oveisi F, Culver BD, Pahl MV, Andersen ME, Strong PL, Murray FJ, The Effect of preganancy on renal clearance of boron in rats given boric acid orally. Toxicol Sci. 2001; 60: 257-263.

6. Kiani F, Khanlarzadeh B, Tahermansouri H, Ab Initio and density functional theory study on ionization of betahistine and cimetidine nano drug in aqueous solution. Farmacia. 2016; 64: 3-8.

7. Nag A, Dey B, Computer-aided drug design and delivery systems, Pharmacology, McGraw Hill Publishing. New York City, New York, United States, 2011.

8. Kibbey CE, Poole SK, Robinson B, Jackson JD, Durham D, An integrated process for measuring the physicochemical properties of drug candidates in a preclinical discovery environment. J Pharm Sci. 2001; 90: 1164-1175.

9. Zhoo L, Agilent Technologies. Inc: Analysis of food additives in beverages using syringe filter filtration and HPLC. USA 2013.

10. Manov GG, DeLollis NJ, Acree SF. ionization constant of boric acid and the $\mathrm{pH}$ of certain borax-chloride buffer solutions from 0 to $60^{\circ} \mathrm{C}$. J Res Natl Bur Stand (U. S.). 1944; 33: 287-306.

11. Arcis H, Ferguson J, Applegarth LMSGA, Zimmerman GH, Tremaine PR. Ionization of boric acid in water from $298 \mathrm{~K}$ to $623 \mathrm{~K}$ by AC conductivity and Raman spectroscopy. J Chem Thermodyn. 2017; 106: 187-198. 
12. Dickson AG. Thermodynamics of the dissociation of boric acid in synthetic seawater from 273.15 to 318.15 K. Deep Sea Research Part A. Oceanographic Research Papers. 1990; 37: 755-766.

13. Almarcha C, Honi YR, de Decker Y, Trevelyan PMJ, Eckert K, de Wit A. Convective mixing induced by acid-base reactions, J Phys Chem. 2011; 115: 9739-9744.

14. Stephens PJ, Devlin FJ, Chabaloeski CF, Frisch MJ, Ab initio calculation of vibrational absorption and circular dichroism spectra using density functional force fields. J Phys chem. 1994, 98: 11623-11627.

15. Soler JM, Artacho E, Gale JD, Garcia A, Junquera J, Ordejon P, Sanchez-Portal D. The siesta method for ab initio order-N materials simulation. J Phys: condensed matter. 2002; 14 : 2745-2779.

16. Greengard L, Fast algorithms for classical physics. Science. 1994; 265: 909-914.

17. Hockney RW, Eastwood JW, Computer Simulation Using Particles (Bristol: Institute of physics publishing), 1998.

18. Car R, Parrinello M , Unified approach for molecular dynamics and density-functional theory. Phys Rev Lett. 1985; 55: 2471.

19. Kiani F, Rostami AA, Sharifi S, Bahadori A, Calculation of acidic dissociation constants of glycylglycine in water at different temperatures using ab initio methods. J Mol Struc: THEOCHEM. 2010, 956: 20-25.

20. Frisch MJ, Trucks GW, Schlegel HB, Scuseria GE, Robb MA, Cheeseman JR. et al., Gaussian 98, revision A.6; Gaussian, Inc.: Pittsburgh, PA, 1998.

21. Miertus S, Tomasi EJ. Approximate evaluations of the electrostatic free energy and internal energy changes in solution processes. Chem Phys. 1982; 65: 239-245.

22. Jeffrey GA, An Introduction to Hydrogen Bonding; Oxford University Press: Oxford, p.p. 303, 1997.

23. Goldberg R. N., Kishore N., Lennen R. M. Thermodynamic quantities for the ionization reactions of buffers. Journal of Physical and Chemical Reference Data, 31, 2002, 231-370. 


\section{Tables}

Table1- The calculated total free energy $\left(\mathrm{G}^{\mathrm{o}}\right.$ sol $)$ using the Tomasi method at the B3LYP/6$31+\mathrm{G}(\mathrm{d})$ level of theory for neutral and cationic species of boric acid at $298.15 \mathrm{~K}$.

\begin{tabular}{cccc}
\hline No & species & $\mathrm{G}^{\mathbf{o}}$ sol $($ Hartree $)$ & $\mathrm{G}^{\mathrm{o}}$ sol/molecule $\left(\mathrm{kJ}^{\left.-\mathrm{mol}^{-1}\right)}\right.$ \\
\hline 0 & $\mathrm{H}_{2} \mathrm{~L}^{-}$ & -252.913276 & -664023.7424 \\
1 & $\mathrm{H}_{2} \mathrm{~L}^{-}\left(\mathrm{H}_{2} \mathrm{O}\right)$ & -329.373889 & -432385.5313 \\
2 & $\mathrm{H}_{2} \mathrm{~L}^{-}\left(\mathrm{H}_{2} \mathrm{O}\right)_{2}$ & -405.824119 & -355163.7074 \\
3 & $\mathrm{H}_{2} \mathrm{~L}^{-}\left(\mathrm{H}_{2} \mathrm{O}\right)_{3}$ & -482.272605 & -316551.6507 \\
4 & $\mathrm{H}_{2} \mathrm{~L}^{-}\left(\mathrm{H}_{2} \mathrm{O}\right)_{4}$ & -558.723888 & -293385.8854 \\
0 & $\mathrm{HL}$ & -252.517526 & -662984.7009 \\
1 & $\mathrm{H}_{3} \mathrm{~L}\left(\mathrm{H}_{2} \mathrm{O}\right)$ & -328.959459 & -431841.4884 \\
2 & $\mathrm{H}_{3} \mathrm{~L}\left(\mathrm{H}_{2} \mathrm{O}\right)_{2}$ & -405.403531 & -354795.6228 \\
3 & $\left.\mathrm{H}_{3} \mathrm{~L}_{2} \mathrm{H}_{2} \mathrm{O}\right)_{3}$ & -481.843749 & -316270.1604 \\
4 & $\mathrm{H}_{3} \mathrm{~L}\left(\mathrm{H}_{2} \mathrm{O}\right)_{4}$ & -558.291915 & -293159.0564 \\
0 & $\mathrm{H}_{3} \mathrm{O}^{+}$ & -76.862 & -201801.1616 \\
0 & $\mathrm{H}_{2} \mathrm{O}$ & -76.434 & -200677.4477 \\
0 & $\mathrm{OH}^{-}$ & -75.952 & -199411.9569 \\
\hline
\end{tabular}

Table 2. The Value of $\mathrm{pK}_{\mathrm{a}}$ for the deprotonation of boric acid obtained using the Tomasi's method at the B3LYP/6-31+G (d) level of theory, at $298.15 \mathrm{~K}$.

specie selected equations $\mathrm{pK}_{\mathrm{a}}$ (calculated) $\mathrm{pK}_{\mathrm{a}}$ (experimental)

$\begin{array}{lll}\text { boric acid } & \mathrm{H}_{3} \mathrm{~L}\left(\mathrm{H}_{2} \mathrm{O}\right)_{4} \rightleftharpoons \mathrm{H}_{2} \mathrm{~L}^{-}\left(\mathrm{H}_{2} \mathrm{O}\right)_{3}+\mathrm{H}_{3} \mathrm{O}^{+} & 9.36436\end{array} 9.237^{\mathrm{a}}$

a: Ref. [23]

Table 3- The calculated structural properties for the neutral and cation species of boric acid using Tomasi's method at the B3LYP/6-31+G (d) level of theory at $298.15 \mathrm{~K}$.

\begin{tabular}{ccc}
\hline Specie & \multicolumn{2}{c}{ calculated magnitudes } \\
\hline boric acid & $\mathrm{H}_{2} \mathrm{~L}\left(\mathrm{H}_{2} \mathrm{O}\right)_{4}$ & $\mathrm{HL}^{-}\left(\mathrm{H}_{2} \mathrm{O}\right)_{3}$ \\
\hline $\mathrm{K}_{\mathrm{c}}$ & 2313964803 & - \\
$\mathrm{K}_{\mathrm{a}}$ & $2.2956 \mathrm{E}+23$ & - \\
$\mathrm{qB}_{1}$ & 1.311027 & 1.174291 \\
$\mathrm{qO}_{2}$ & -1.018240 & -0.947905 \\
$\mathrm{qO}_{3}$ & -1.132647 & -0.912080
\end{tabular}




\begin{tabular}{|c|c|c|}
\hline $\mathrm{qO}_{4}$ & -0.907847 & -1.104481 \\
\hline $\mathrm{qH}_{7}$ & 0.650111 & 0.605440 \\
\hline $\mathrm{qO}_{9}$ & -1.093296 & - \\
\hline $\mathrm{qH}_{11}$ & 0.549604 & - \\
\hline $\mathrm{qH}_{13}$ & 0.562297 & 0.557999 \\
\hline $\mathrm{qH}_{16}$ & 0.637048 & 0.539621 \\
\hline $\mathrm{qH}_{19}$ & - & 0.599065 \\
\hline $\mathrm{qH}_{20}$ & - & 0.558377 \\
\hline $\mathrm{dO}_{2} \mathrm{~B}_{1}$ & 1.382044 & 1.357259 \\
\hline $\mathrm{dO}_{3} \mathrm{~B}_{1}$ & 1.384941 & 1.366905 \\
\hline $\mathrm{dO}_{4} \mathrm{~B}_{1}$ & 1.355540 & 1.412990 \\
\hline $\mathrm{dH}_{5} \mathrm{O}_{2}$ & 0.971181 & 0.979039 \\
\hline $\mathrm{dH}_{6} \mathrm{O}_{3}$ & 0.991077 & - \\
\hline $\mathrm{dH}_{7} \mathrm{O}_{3}$ & - & 0.977600 \\
\hline $\mathrm{dH}_{7} \mathrm{O}_{4}$ & 0.967252 & - \\
\hline $\mathrm{dO}_{8} \mathrm{O}_{4}$ & 2.788456 & - \\
\hline $\mathrm{dO}_{9} \mathrm{O}_{3}$ & 3.841056 & $-\quad$ \\
\hline $\mathrm{dH}_{11} \mathrm{O}_{9}$ & 0.973583 & -1 \\
\hline $\mathrm{dH}_{13} \mathrm{O}_{12}$ & - & 0.968626 \\
\hline $\mathrm{dH}_{6} \mathrm{O}_{9}$ & 2.124582 & - \\
\hline $\mathrm{dH}_{19} \mathrm{O}_{2}$ & - & 2.098563 \\
\hline $\mathrm{AO}_{3} \mathrm{~B}_{1} \mathrm{O}_{2}$ & 114.708261 & 119.682443 \\
\hline $\mathrm{AO}_{4} \mathrm{~B}_{1} \mathrm{O}_{2}$ & 118.806632 & 118.757031 \\
\hline $\mathrm{AH}_{5} \mathrm{O}_{2} \mathrm{~B}_{1}$ & 111.895234 & 112.464635 \\
\hline $\mathrm{AH}_{6} \mathrm{O}_{3} \mathrm{~B}_{1}$ & 121.477128 & - \\
\hline $\mathrm{AH}_{7} \mathrm{O}_{3} \mathrm{~B}_{1}$ & $(-1)$ & 111.480812 \\
\hline $\mathrm{AO}_{9} \mathrm{O}_{3} \mathrm{~B}_{1}$ & 144.288763 & - \\
\hline $\mathrm{AH}_{10} \mathrm{O}_{9} \mathrm{O}_{3}$ & 115.173761 & - \\
\hline $\mathrm{AH}_{11} \mathrm{O}_{9} \mathrm{O}_{3}$ & 139.273690 & - \\
\hline $\mathrm{AH}_{13} \mathrm{O}_{12} \mathrm{O}_{3}$ & J - & 147.569337 \\
\hline $\mathrm{AH}_{16} \mathrm{O}_{15} \mathrm{O}_{3}$ & - & 130.127543 \\
\hline $\mathrm{DO}_{4} \mathrm{~B}_{1} \mathrm{O}_{2} \mathrm{O}_{3}$ & -179.779914 & -178.510094 \\
\hline $\mathrm{DH}_{5} \mathrm{O}_{2} \mathrm{~B}_{1} \mathrm{O}_{4}$ & 3.701327 & -177.469800 \\
\hline $\mathrm{DH}_{6} \mathrm{O}_{3} \mathrm{~B}_{1} \mathrm{O}_{4}$ & 14.750747 & - \\
\hline $\mathrm{DH}_{7} \mathrm{O}_{3} \mathrm{~B}_{1} \overline{\mathrm{O}}_{4}$ & 177.137823 & -171.677912 \\
\hline $\mathrm{DH}_{10} \mathrm{O}_{9} \mathrm{O}_{3} \mathrm{~B}_{1}$ & -18.098064 & - \\
\hline $\mathrm{DH}_{13} \mathrm{O}_{12} \mathrm{O}_{3} \mathrm{~B}_{1}$ & - & 147.569337 \\
\hline $\mathrm{DH}_{16} \mathrm{O}_{15} \mathrm{O}_{3} \mathrm{~B}_{1}$ & - & 130.127543 \\
\hline
\end{tabular}

$\mathrm{K}_{\mathrm{C}}$, equilibrium constant of equation; $\mathrm{K}_{\mathrm{a}}$, acidic dissociation constants of species in water; $\mathrm{D}$, dihedral angle between the indicated atoms $(\AA)$; q, total atomic charge (Muliken) (au); d, bond lengths between the indicated atoms; A, angles $\left({ }^{\circ}\right)$. 


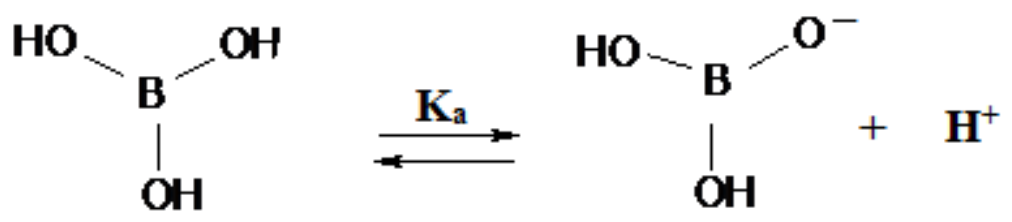

Figure 1- The scheme of deporotonation of boric acid

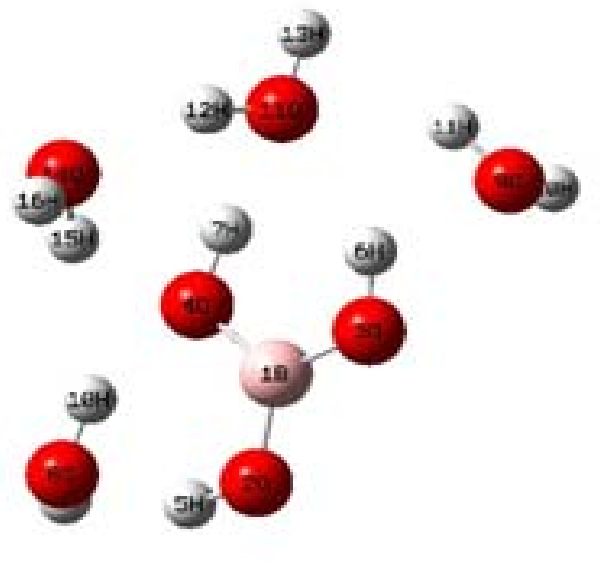

(A): $\mathrm{H}_{3} \mathrm{~L}\left(\mathrm{H}_{2} \mathrm{O}\right)_{4}$

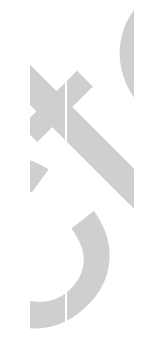

Figure 2- The calculated structure for the neutral (A) and cation (B) species of boric acid solvated with four and three water molecules, respectively, obtained at the B3LYP/6$31+\mathrm{G}(\mathrm{d})$ level of theory and using Tomasi's method at $298.15 \mathrm{~K}$. 